\title{
Optimization Method for Proteomic Analysis of the Larva and Adult Tissues of Plutella xylostella (L.) (Lepidoptera: Plutellidae)
}

(Pengoptimuman Kaedah Proteomik bagi Tisu Larva dan Dewasa Plutella xylostella (L.) (Lepidoptera: Plutellidae))

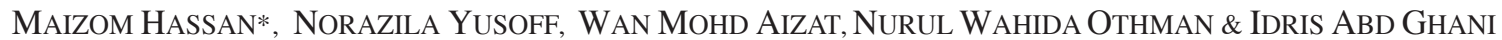

\begin{abstract}
Plutella xylostella (L.) (Lepidoptera: Plutellidae), the major insect pest of cruciferous crops worldwide shows significant resistance to almost all classes of insecticides. In order to effectively prevent and manage the insecticidal resistance, it is crucial to understand the physiological adaptation of insects against insecticides. Identification of insect protein that interacting with insecticides and characterization of their modification in resistant strains can be done by using differential proteomics approach. This study focuses on optimizing a sensitive and rapid method for the extraction of high quality protein of both larva and adult tissues of $\mathrm{P}$. xylostella to be used in two-dimensional gel electrophoresis. Five extraction methods were evaluated for protein concentration, yields and resolving patterns of one-dimensional and two-dimensional electrophoresis. The results showed that trichloroacetic acid/acetone extraction methods with two different concentrations of 2-mercaptoethanol produced the highest protein concentration and yield for both adult and larva tissues, respectively. Meanwhile, trichloroacetic acid/acetone with dithiothreitol extraction method gave better separation of spots and intensity for both larva and adult tissues compared to other methods tested. As such, we concluded that trichloroacetic acid/acetone with dithiothreitol successfully yielded high total protein concentration and good separation of two-dimensional electrophoresis gel spots in both adult and larva P. xylostella.
\end{abstract}

Keywords: Optimization; Plutella xylostella (L.); protein extraction; proteomics; two-dimensional gel electrophoresis

ABSTRAK

Plutella xylostella (L.) (Lepidoptera: Plutellidae), serangga perosak utama tanaman krusifer di seluruh dunia telah menunjukkan kerintangan yang ketara terhadap hampir semua kelas racun serangga. Pemahaman mengenai penyesuaian fisiologi serangga terhadap racun serangga adalah penting bagi pengurusan yang efektif dan pencegahan kerintangan terhadap racun serangga. Pengenalpastian protein serangga yang berinteraksi dengan racun serangga dan pencirian pengubahsuaian protein serangga yang rintang dapat dilakukan dengan menggunakan pendekatan proteomik pembezaan . Kajian ini memberi tumpuan kepada pengoptimuman kaedah yang lebih sensitif dan cepat untuk pengekstrakan protein berkualiti tinggi daripada kedua-dua tisu larva dan dewasa P. xylostella untuk digunakan dalam elektroforesis gel dua dimensi. Lima kaedah pengekstrakan telah dinilai berdasarkan kepekatan protein, jumlah protein dan corak gel elektroforesis satu dimensi dan dua dimensi. Keputusan menunjukkan bahawa kaedah pengekstrakan asid trikloroasetik/ aseton dengan dua kepekatan 2-merkaptoetanol yang berbeza menghasilkan kepekatan dan jumlah protein paling tinggi bagi kedua-dua tisu larva dan dewasa. Sementara itu, kaedah pengekstrakan asid trikloroasetik/aseton dengan dithiothreitol memberikan pemisahan titik protein dan keamatan yang lebih baik bagi kedua-dua tisu larva dan dewasa berbanding kaedah lain. Oleh itu, dapat disimpulkan bahawa pengekstrakan menggunakan kaedah asid trikloroasetik/ aseton dengan dithiothreitol berjaya menghasilkan kepekatan jumlah protein yang tinggi dan pemisahan protein yang baik untuk gel elektroforesis dua dimensi bagi kedua-dua tisu dewasa dan larva P. xylostella.

Kata kunci: Elektroforesis gel dua dimensi; pengekstrakan protein; pengoptimuman; Plutella xylostella (L.); proteomik

\section{INTRODUCTION}

The diamondback moth, P. xylostella (Lepidoptera: Plutellidae) has become the most destructive pest for cruciferous crops all over the world (Mahmoudvand et al. 2011). The annual damage and management costs for controlling this pest was estimated to be 4 to 5 billion dollars globally (Zalucki et al. 2012). The extensive use of insecticides in controlling this pest has resulted in the emergence of resistance moths and it has caused major problem to the farmers (Bates et al.2005). Moreover, it has developed resistance to as many as 95 active ingredients including abamectin, chlorantraniliprole, deltametrin, fenvalerate, fipronil, indoxacarb, spinosad and triflumuron (Arthropod Pesticide Resistance Database 2018). In order to effectively manage such resistance, it is essential to elucidate the behaviour, biochemical and physiological adaptations inside $P$. xylostella in response to the exposure of insecticides or toxic compounds.

Proteomics has played as one of the powerful method to understand molecular changes at the protein level. Insect 
proteomics has become a rapidly evolving field of research, wherein efforts are continuing for profiling and analyzing the proteome content of any given insects either at the organelle or at individual (Shashank \& Bollineni 2014). Recent studies on insect proteomics have given insight into the molecular mechanisms of larva development, diapauses and resistance mechanisms (Colinet et al. 2012; Konus et al. 2013; Li et al. 2014a; Yin et al. 2017; Zhang et al. 2013). Differential proteomics which aimed to understand protein regulation during normal and treatment status were applied in several insecticides resistance and susceptibility response studies of $P$.xylostella (Dong et al. 2013; Xie et al. 2011; Yin et al. 2017; Zhang et al. 2013). These results suggested that the insecticides treatment have induced alteration in protein, which are participated in the nervous transduction and multiple metabolic pathways.

Two-dimensional gel electrophoresis (2-DE) combined with mass spectrometry are frequently used in proteomic research. The sample quality and protein extraction are most important thing in all proteomics analysis. Optimizing the technical processes in 2-DE analysis involving several stages including sample preparation, protein solubilization and also prefractionation procedures (Görg et al. 2004; Isaacson et al. 2006; Shaw \& Riederer 2003; Wu et al. 2011). Incomplete precipitation and/or resolubilization will result in losses of protein (Wu et al. 2011). Besides, removing of interfering compounds such as proteolytic enzymes, lipids, nucleic acids, and salts during cell lysis can prevent artifactural spots and loss of high molecular weight proteins (Görg et al. 2004; Shaw \& Riederer 2003). In addition, both unsaturated and saturated fatty acids are found in Lepidoptera insects (Amadi \& Kiin-Kabari 2016; Etebari et al. 2007; Khani et al. 2007; Wang et al. 2006; $\mathrm{Xu}$ et al. 2016). Lipids bind proteins through hydrophobic interactions and will affect their charge and molecular weight. Protein extract with high content of lipids will caused distortion and smearing of the one-dimensional electrophoresis (1-DE) gel pattern (Saravanan \& Rose 2004; Shaw \& Riederer 2003; Wang et al. 2006). Hence, the optimization of protein extraction method from $P$. xylostella is critical to obtain clean samples for subsequent proteomics analysis.

There are several studies mentioning the development of optimal protein sample extraction methods for proteomics analysis of different tissues or certain stages of P. xylostella. For instance, trichloroacetic acid (TCA)/ acetone with 2-mercaptoethanol (2-ME) method was used for protein preparation from the larva stage of $P$. xylostella (Xie et al. 2011) while tris lysis buffer methods were applied to extract the protein from $P$. xylostella adult tissues (Dong et al. 2013). In addition, TCA-acetone with dithiothreitol (DTT) was used to extract the protein from P. xylostella adult (Zhang et al. 2013) and larva (Yin et al. 2017) tissues. As different buffers/methods may lead to different proteins extracted (Carpentier et al. 2005; Gómez-Vidal et al. 2008; Saravanan \& Rose 2004; Xu et al 2008), a simpler and single extraction method which can applied for both larva and adult stages of P. xylostella is needed in order to analyze and compare its proteome more accurately.

Numerous protein extraction methods for 1-DE and 2-DE have been developed and applied for various plant samples (Alam et al. 2012; Chatterjee et al. 2012; GómezVidal et al. 2008; Isaacson et al. 2006; Rasool et al 2014; Vincent et al. 2006; Xu et al. 2008; Zhang et al. 2015; Zheng et al. 2007). Compared to the optimal methods for the extraction of plant tissues, only a few studies in the literature that compare different extraction methods for insect tissues (Cilia et al. 2009; Collet \& Baguñà 1993; Qin et al. 2013; Wang et al.2010; Yiou et al.2013), particularly for larva and adult tissues of P. xylostella. The major drawback in proteomics research of $P$. xylostella is the lack of reliable protein extraction methods (Dong et al. 2013; Li et al. 2014a; Xie et al. 2011; Yin et al. 2017; Zhang et al. 2013). Thus, the development of efficient protein extraction methods for larva and adult tissues of $P$. xylostella will expedite proteomic studies of this Lepidoptera pest.

The aim of the present study was to find an optimal method for extracting the total protein of P.xylostella for subsequent one-dimensional electrophoresis (1-DE) and 2 -DE analyses. We employed five different extraction methods (Cilia et al. 2009; Dong et al. 2013; Li et al. 2014b; Xie et al. 2011; Zhang et al.2013) on both larva and adults of $P$. xylostella. These methods were chosen based on their successful used previously for extracting proteins from various insect samples including $P$. xylostella, albeit from different types of tissues or stages. Furthermore, these methods employ different strategies for the protein extraction, for example using different extraction buffers as well as precipitating steps, yet no direct comparison has been made to assess their extraction efficiency. Therefore, such efficiency was assessed by comparing their protein yields, protein bands from 1-DE gels as well as number of distinct protein spots in 2-DE gels. To the best of our knowledge, this is the first report on protein extraction methods for both larva and adult tissues of P. xylostella.

\section{MATERIALS AND METHODS}

\section{CHEMICALS}

BlueEye prestained protein marker (GeneDirex, Taiwan) was used as a molecular weight standard for sodium dodesyl sulphate polyacrylamide gel electrophoresis (SDSPAGE) and 2-DE. Protease inhibitor cocktail was obtained from Nacalai Tesque (Japan). All other chemicals were commercial products of analytical grade.

\section{INSECT REARING}

The P. xylostella insects were collected from vegetable farms in Cameron Highlands, Pahang, Malaysia (4.5820 $\left.\mathrm{N}, 101.4115^{\circ} \mathrm{E}\right)$ and brought to the laboratory at the Institute of Systems Biology (INBIOSIS), Universiti Kebangsaan Malaysia (UKM) for rearing. Larva were maintained on four-week old mustard plants, Brassica 
rapa in rearing cages $(35 \mathrm{~cm} \times 35 \mathrm{~cm} \times 47 \mathrm{~cm})$ at $25 \pm$ $1^{\circ} \mathrm{C}$ with a photoperiod of $12 \mathrm{~h}$ light and $12 \mathrm{~h}$ dark. The mustard plants were grown on an organic planting soil in a plastic pot with $14 \mathrm{~cm}$ in diameter and $12 \mathrm{~cm}$ in depth. Plants were watered twice a day to prevent wilting. The newly emerged adults were transferred to new mustard plants for oviposition and cotton wool wetted with $10 \%$ honey water solution was used as a dietary supplement. The experiments were started after five generations of reared P. xylostella.

\section{PROTEIN EXTRACTION METHODS}

Five total protein extraction methods were performed and compared to obtain the best protein yield for both larva and adult samples of P.xylostella. Prior to each method of extraction, $0.1 \mathrm{~g}$ of whole third instar larva and one-day old adults were ground to a fine powder in liquid nitrogen using a prechilled mortar and pestle, transferred to a $2 \mathrm{~mL}$ eppendorf tube and the proteins were extracted as described below (Method A to E). Throughout protein extraction procedures, buffer containing of $7 \mathrm{M}$ urea, $2 \mathrm{M}$ thiourea and 2\% 3-[(3-cholamidopropyl)dimethylammonio]-1propanesulfonate was used as rehydration buffer (RB) unless otherwise specified. All centrifugation steps were carried out at $4^{\circ} \mathrm{C}$ unless stated differently.

\section{METHOD A}

The method was performed according to Cilia et al. (2009) with minor modification. Frozen tissues were added directly into $10 \%$ TCA in acetone containing $2 \%$ 2-mercaptoethanol (2-ME) and mixed by inverting the tubes for 10 times. Proteins were precipitated overnight at $-20^{\circ} \mathrm{C}$. Precipitated proteins were centrifuged at 5,000 $\mathrm{g}$ for $30 \mathrm{~min}$. The pellets were then washed 3 times in icecold acetone before being air-dried at room temperature and resuspended in $500 \mu \mathrm{L}$ RB.

\section{METHOD B}

Method B was slightly modified from a published method (Xie et al. 2011). Proteins were extracted in 10\% TCA in acetone containing $0.7 \%$ 2-ME and mixed by vortexing for $5 \mathrm{~min}$. The proteins were allowed to precipitate overnight at $-20^{\circ} \mathrm{C}$. Precipitated proteins were centrifuged at $15,000 \mathrm{~g}$ for $30 \mathrm{~min}$. The precipitates were washed with $80 \%$ acetone followed by ice-cold pure acetone and air-dried at room temperature before redissolved in $500 \mu \mathrm{L}$ RB.

\section{METHOD C}

Proteins were prepared according to the method described by Zhang et al. (2013) with slightly modification. One $\mathrm{mL}$ extraction buffer containing $10 \%$ TCA in acetone and $40 \mathrm{mM}$ dithiothreitol (DTT) was added to the samples and the mixtures were suspended at $-20^{\circ} \mathrm{C}$ for $1 \mathrm{~h}$. The samples were then centrifuged at $15,500 \mathrm{~g}$ for $30 \mathrm{~min}$. The precipitates were resuspended three times in ice-cold acetone for $1 \mathrm{~h}$ at $-20^{\circ} \mathrm{C}$, followed by centrifugation at $13,200 \mathrm{~g}$ for $10 \mathrm{~min}$. The proteins were then resuspended in $\mathrm{RB}$ for $2 \mathrm{~h}$ at $4^{\circ} \mathrm{C}$, followed by centrifugation at 15,500 $g$ for $30 \mathrm{~min}$ and the supernatant was stored at $-80^{\circ} \mathrm{C}$.

\section{METHOD D}

Method D was slightly modified from a published method (Dong et al. 2013). Proteins were extracted in 1 $\mathrm{mL}$ of pre-cooled lysis buffer (7 M urea, $2 \mathrm{M}$ thiourea, $4 \% 3$-[(3-cholamidopropyl)dimethylammonio]-1propanesulfonate, $30 \mathrm{mM}$ tris- $\mathrm{HCl}$ and protease inhibitor cocktail, homogenized and sonicated $(10 \times 15 \mathrm{~s}$ pulses $)$ on ice. The mixtures were centrifuged at 13, $200 \mathrm{~g}$ for $30 \mathrm{~min}$. The supernatants were transferred to new eppendorf tubes and precipitated with cold acetone at $-20^{\circ} \mathrm{C}$ for $4 \mathrm{~h}$. The precipitates were washed with cold acetone at $-20^{\circ} \mathrm{C}$ for 2 times and centrifuged at $12,000 \mathrm{~g}$ for $15 \mathrm{~min}$. The pellets were dried at room temperature for $5 \mathrm{~min}$ and redissolved in $500 \mu \mathrm{L}$ RB.

\section{METHOD E}

Proteins were extracted according to the method described by Li et al. (2014b) with slightly modification. Frozen tissues were added to $1 \mathrm{~mL}$ of phosphate buffer solution (PBS) (32.5 mM K $\mathrm{HPO}_{4}, 2.6 \mathrm{mM} \mathrm{KH}_{2} \mathrm{PO}_{4}, 400 \mathrm{mM} \mathrm{NaCl}$ and protease inhibitor cocktail and placed on ice for 15 $\min$. The mixtures were then centrifuged at $12,000 \mathrm{~g}$ for $10 \mathrm{~min}$ and further centrifuged at $15,000 \mathrm{~g}$ for $10 \mathrm{~min}$. The precipitates were resuspended with the PBS (1 mg sample/5 mL buffer), then centrifuged at $15,000 \mathrm{~g}$ for 10 min. Supernatants were transferred to new tubes and TCA were added to the supernatants to reach $10 \%$ of the final concentration, and then kept on ice for $10 \mathrm{~min}$. These mixtures were centrifuged at $15,000 \mathrm{~g}$ for $20 \mathrm{~min}$. The pellets were washed 3 times in ice-cold acetone containing $0.2 \%$ DTT and then air-dried at room temperature and redissolved in the RB containing a cocktail of protease inhibitors. The pellet then was brought to room temperature for $2 \mathrm{~h}$, then it was centrifuged at 15,000 $\mathrm{g}$ for $30 \mathrm{~min}$.

\section{MEASUREMENT OF PROTEIN}

The protein concentration was determined according to the method developed by Bradford (1976) using bovine serum albumin to generate standard curve. Total protein was expressed as microgram per gram fresh weight (FW) of adult or larva tissues weight.

\section{1-DE ANALYSIS}

1-DE analysis was carried out as mentioned by Laemmli (1970) with protein pellets redissolved in SDS-PAGE buffer. $12.5 \%$ acrylamide separating gel and $4 \%$ stacking gel were used for SDS-PAGE. BlueEye prestained protein marker, which has a standard-protein molecular-weight range of approximately $10-245 \mathrm{kDa}$, was used as molecular marker. The gels were run at $75 \mathrm{~V}$ for $25 \mathrm{~min}$ and then at $125 \mathrm{~V}$ 
for $1 \mathrm{~h}$ in a Mini-Protean 3 cell (Bio-Rad, USA). After electrophoresis, the gels were stained in Coomassie Blue $\mathrm{R}-250$ (CBB) (Bio-Rad, USA) and destained in a solution containing $40 \%$ methanol and $10 \%$ glacial acetic acid.

\section{2-DE ANALYSIS}

For 2-DE analysis of extracted proteins, the first isoelectric focusing (IEF) dimension was carried out on IPG strips $(7 \mathrm{~cm}$, 3-10 linear $\mathrm{pH}$ gradient; Bio-Rad) which were passively rehydrated for $15 \mathrm{~h}$ with $300 \mu \mathrm{g}$ of proteins in rehydration buffer (8.0 M urea, 4\% (w/v) 3-[(3-cholamidopropyl) dimethylammonio]-1-propanesulfonate, $0.5 \%(\mathrm{v} / \mathrm{v}) \mathrm{of} \mathrm{pH}$ 3-10 ampholites, $30 \mathrm{mM}$ 2-ME, and $0.002 \%$ bromophenol blue) (Seman-Kamarulzaman et al. 2016). The isoelectric focusing was carried out using Ethan IPGphor (GE Healthcare Bioscience, Uppsala, Sweden) according to the manufacturer's instructions. Following first dimension separation for $17,700 \mathrm{Vh}$ at $20^{\circ} \mathrm{C}(200 \mathrm{~V}$ for $200 \mathrm{Vh}, 500 \mathrm{~V}$ for $500 \mathrm{Vh}, 1000 \mathrm{~V}$ for $1000 \mathrm{Vh}$ and $4000 \mathrm{~V}$ for $16000 \mathrm{Vh}$ ), strips were equilibrated for $15 \mathrm{~min}$ at room temperature with an equilibration buffer ( $6 \mathrm{M}$ urea, $50 \mathrm{mM}$ tris- $\mathrm{HCl}$ ( $\mathrm{pH}$ 8.8), 30\% glycerol, $2 \%$ SDS) containing $1 \%$ DTT, followed for 15 min with the same buffer but containing $2.5 \%$ iodoacetamide. The second dimension was performed on $12.5 \%$ SDS-PAGE home-cast gels and run at $13 \mathrm{~mA}$ per strip for $15 \mathrm{~min}, 16 \mathrm{~mA}$ per strip for $20 \mathrm{~min}$ and $18 \mathrm{~mA}$ per strip until the bromophenol blue front reached the bottom of the gels. The gels were stained with CBB. Quantitive analysis of images was performed with PDQuest (Bio-Rad, USA) according to the protocol provided by the manufacturer. Experimental molecular weight values were calculated by mobility comparisons with standard protein markers loaded in a separate lane on the SDS-PAGE gel, while isoelectric point was determined by using linear scale of a 3-10 scale over the the total dimension of the IPG strip.

\section{RESULTS}

\section{PROTEIN YIELD}

Extraction methods were first compared by quantifying the total protein concentration and yield (Table 1 ). Protein concentration and total protein yield of extracted proteins rely upon the method used. The values for both parameters were varied greatly between methods, ranging from 1.8 to $17.4 \mathrm{mg} / \mathrm{mL}$ and 9.0 to $87.0 \mathrm{mg} / \mathrm{g}$ fresh weight (FW) for concentration and yield of different tissue types, respectively. Method B and A gave the greatest concentration and yield for larva and adult samples, respectively. Protein quantification showed that Method $\mathrm{B}$ and $\mathrm{C}$ produced almost equal amount of protein from larva sample of $0.1 \mathrm{~g}$. However, relative amount of protein from Method E based on phosphate buffer yielded 15 $\mathrm{mg}$ proteins $/ 0.1 \mathrm{~g}$ larva sample, while buffer $\mathrm{D}$ based on Tris- $\mathrm{HCl}$ extraction buffer gave the lowest yield $(9 \mathrm{mg} / \mathrm{g})$. In contrast, Method C, D, and E yielded almost similar amount of protein for $0.1 \mathrm{~g}$ of adult sample. However, further analysis in terms of protein quality and quantity are needed to verify the protein extracts from these different methods.

\section{1-DE ANALYSIS}

Relative quality and quantity of total proteins extracted through several extraction methods were confirmed by

TABLE 1. The concentration, total protein yield, and number of protein spots of P.xylostella extracted with five different extraction methods

\begin{tabular}{|c|c|c|c|c|c|c|c|}
\hline \multirow[t]{2}{*}{ Method } & \multirow[t]{2}{*}{ Extraction buffer } & \multicolumn{2}{|c|}{$\begin{array}{l}\text { Protein concentration } \\
\qquad(\mathrm{mg} / \mathrm{mL})\end{array}$} & \multicolumn{2}{|c|}{$\begin{array}{l}\text { Total protein yield } \\
(\mathrm{mg} / \mathrm{g})\end{array}$} & \multicolumn{2}{|c|}{$\begin{array}{l}\text { Number of protein } \\
\text { spots }\end{array}$} \\
\hline & & Larvae & Adult & Larvae & Adult & Larvae & Adult \\
\hline A & $\begin{array}{l}10 \% \text { TCA-acetone, } \\
2 \% 2 \text { - mercaptoethanol }\end{array}$ & $6.63 \pm 0.26$ & $17.43 \pm 0.37$ & $33.17 \pm 1.30$ & $87.17 \pm 1.86$ & 246 & 256 \\
\hline $\mathrm{B}$ & $\begin{array}{l}10 \% \text { TCA- acetone, } \\
0.7 \% \text { 2- mercaptoethanol }\end{array}$ & $11.30 \pm 0.4$ & $10.40 \pm 0.23$ & $56.5 \pm 2.00$ & $52.00 \pm 1.16$ & 153 & 208 \\
\hline $\mathrm{C}$ & $\begin{array}{l}10 \% \text { TCA- acetone, } \\
40 \text { mM DTT }\end{array}$ & $10.70 \pm 0.57$ & $5.03 \pm 0.48$ & $53.5 \pm 2.84$ & $25.17 \pm 2.42$ & 613 & 683 \\
\hline $\mathrm{D}$ & $\begin{array}{l}\text { Tris lysis buffer } \\
\text { (7 M urea, } 2 \mathrm{M} \text { thiourea, } 4 \% \\
\text { 3-[(3-cholamidopropyl) } \\
\text { dimethylammonio]-1- } \\
\text { propanesulfonate, } 30 \mathrm{mM} \text { Tris- } \mathrm{HCl} \\
\text { and protease inhibitor cocktail) }\end{array}$ & $1.8 \pm 0.1$ & $5.37 \pm 0.12$ & $9.08 \pm 0.08$ & $26.83 \pm 0.60$ & 52 & 128 \\
\hline $\mathrm{E}$ & $\begin{array}{l}\text { Phosphate buffer } \\
\left(32.5 \mathrm{mM} \mathrm{K}_{2} \mathrm{HPO}_{4}, 2.6 \mathrm{mM} \mathrm{KH}_{2} \mathrm{PO}_{4} \text {, }\right. \\
400 \mathrm{mMNaCl} \text { and protease inhibitor } \\
\text { cocktail) }\end{array}$ & $2.97 \pm 0.49$ & $5.97 \pm 0.09$ & $14.83 \pm 2.46$ & $29.83 \pm 0.44$ & 94 & 131 \\
\hline
\end{tabular}


1-DE and 2-DE analyses. Approximately, $5 \mu \mathrm{g}$ aliquots of each protein extract was solubilized in SDS loading buffer and separated on a $12.5 \%$ SDS-PAGE before staining. Figure 1 shows typical results obtained from 1-DE on both tissues of P. xylostella protein. Regardless types of reducing agents in the buffer, proteins obtained from TCA/ acetone buffer methods (Method A, B, C) either from larva or adult tissues were well separated by SDS-PAGE and displayed recognizable polypeptide bands from 10 to $245 \mathrm{kDa}$. Nonetheless, Method D and Method E produced much lower protein band intensity despite the same loading protein amount for all wells $(5 \mu \mathrm{g})$. In contrast, all 5 extraction methods showed similar pattern of protein bands for adult samples, although Method A was observed to have slightly more intense bands than other methods.

\section{2-DE ANALYSIS}

Extraction methods were then compared by 2-DE (Figures 2 and 3). The first-dimensional IEF step of protein extracts from larva and adult samples were analyzed by using 3-10 linear IPG strips and the resulting 2-DE gel revealed that most of protein spots were focused in the 3-7 $\mathrm{pH}$ range. For the larva sample, Methods A, B and C were better in terms of spot separation and spot intensity compared to Method D and Method E (Figure 2), consistent with their respective quality in the 1-DE gel earlier (Figure 1). Protein spot quantity was also higher in the former three extraction methods (more than 150 spots) compared to the Method D and Method E (less than 100 spots) (Table 1). A similar finding was also observed in 2-DE gels of adult sample. Better gels with more defined spots were obtained from Method A, B and C (more than 200 spots) compared to the latter methods (approximately 130 spots) (Table 1, Figure 3).

Interestingly, there were numerous spots of basic pI detected in the protein extracted from Method C. Moreover, most spots were present in the region of between $48 \mathrm{kDa}$ and $75 \mathrm{kDa}$ in both larva and adult tissues of P.xylostella. Method $\mathrm{C}$ also delivered the most abundant protein spots for both of these tissues compared to other methods (613 spots for larva and 683 spots for adult) (Table 1). Whereas, the second best method can only manage to get approximately 250 proteins spots for both samples (Method A), approximately $60 \%$ less spots compared to Method C. The worst performing method was Method D with only 52 and 128 protein spots being detected from both larva and adult proteins, respectively, 80 to $90 \%$ lower number of spots compared to Method C.

\section{DISCUSSION}

A complete proteomic study involving $P$. xylostella at various developmental stages such as larva and adult has not been previously reported. Given that protein extraction method is one of the critical step for a successful proteomic study, an optimization of this extraction method must be done. To accomplish this purpose, five previously existing insect protein extraction protocols were used to extract and solubilize adult and larva tissues from $P$. xylostella for 1DE and 2-DE analysis. Five extraction methods were compared and each method consists of different extraction buffers, reducing agents, protease inhibitors, and steps. These methods were previously used to extract proteins from P. xylostella (Dong et al. 2013; Xie et al. 2011; Zhang et al. 2013), aphid, Schizaphis graminum (Cilia

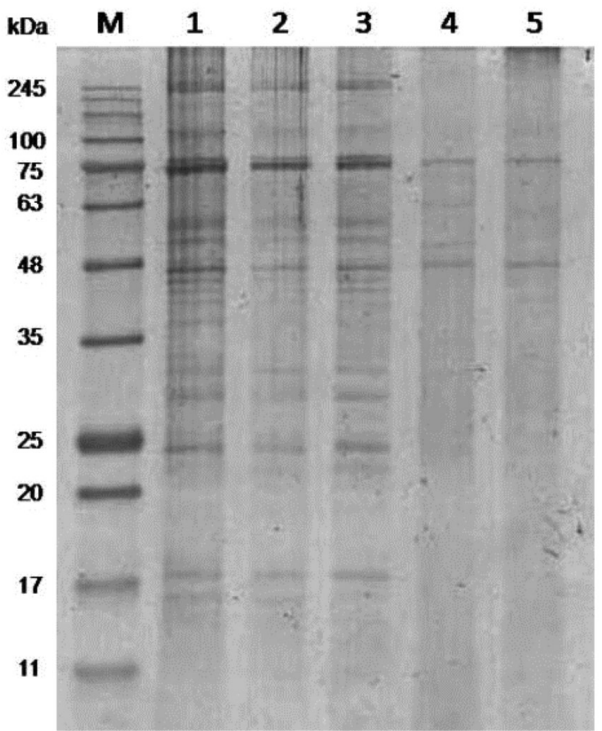

(a)

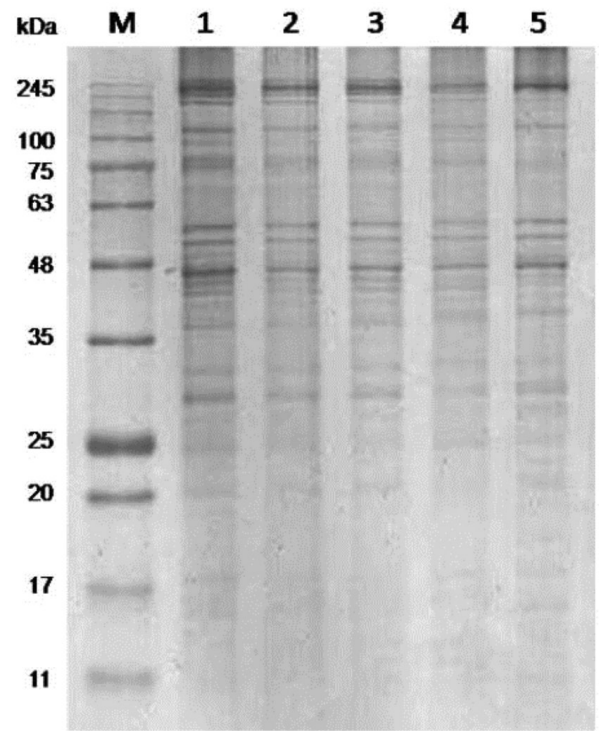

(b)

FIGURE 1. Separation of proteins from P. xylostella larvae (a) and adult (b) protein extracts. Approximately $5 \mu \mathrm{g}$ protein was loaded/lane. M stands for the standard protein marker while lane 1-5 indicate respective methods used for the optimization of protein extraction. Lane 1(Method A), lane 2 (Method B), lane 3(Method C), lane 4 (Method D), lane 5 (Method E) 


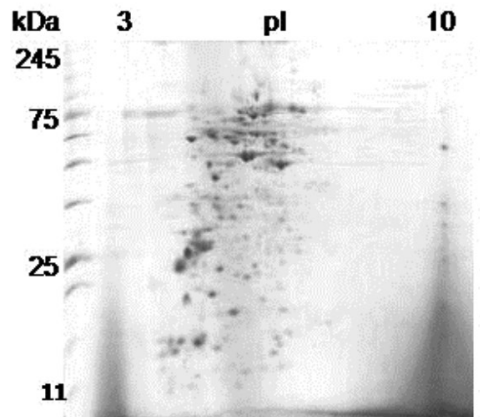

(a)

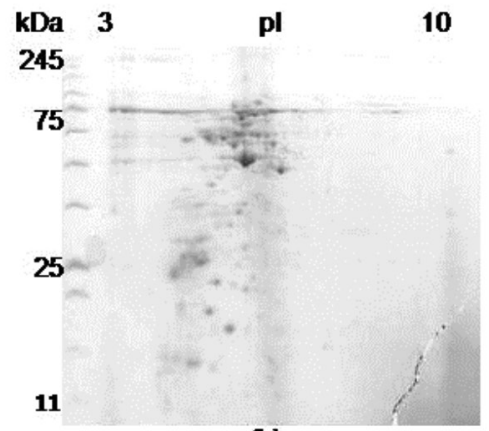

(b)

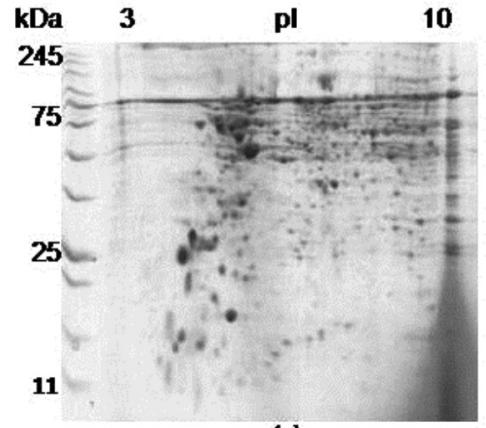

(c)

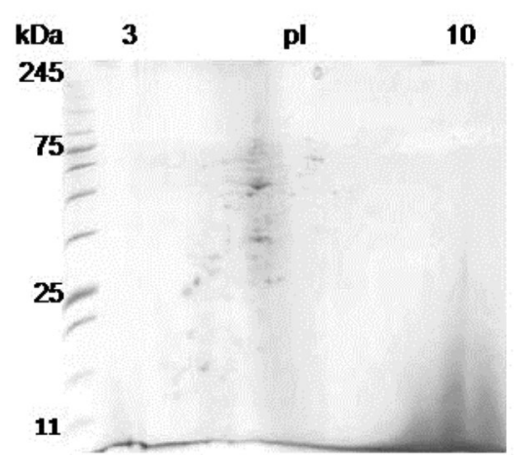

(d)

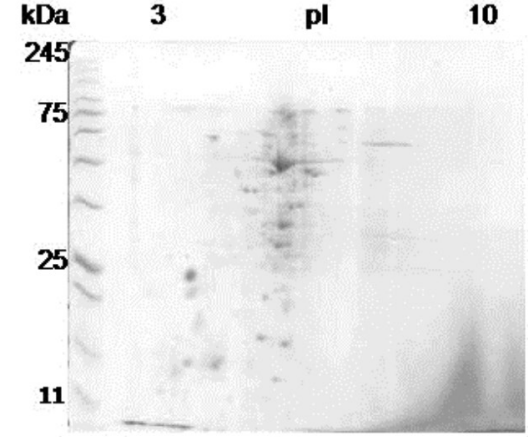

(e)

FIGURE 2. A comparison of P. xylostella larvae protein extracted by different methods using 2-DE. The $7 \mathrm{~cm}, 12.5 \%$ SDS-PAGE gels were stained with CBB. (a) Method A, (b) Method B, (c) Method C, (d) Method D, (e) Method E

et al. 2009) and beetle, Epicauta chinensis ( $\mathrm{Li}$ et al. 2014b) and therefore these methods would be suitable for extraction of $P$. xylostella larva and adult tissues. Three of the extraction methods (Methods A, B and C) were TCA-acetone precipitation with different components and concentration of reducing agents. Meanwhile, Methods $\mathrm{D}$ and $\mathrm{E}$ were extractions using tris-lysis and phosphate buffers, respectively.

Five protein extraction methods that evaluated in the present study were different in their effectiveness and efficiency in protein yield, 1-DE analysis and 2-DE analyses. Protein yield and protein profiling on 1-DE and 2-DE revealed an interesting pattern of the extracted proteins from P.xylostella larva and adult tissues. Methods $A$ and $B$ resulted in significant higher protein yields for both adult and larva tissues, respectively, whereas 2-DE analysis of both protein extracts revealed more than 600 protein spots associated with the Method C. These results suggest that different methods may be suitable for protein extraction of certain types of $P$. xylostella stages or tissues only. Hence, a downstream analysis employing mass spectrometry is needed to confirm the identity of those differentially expressed proteins. In turfgrass plants, $\mathrm{Xu}$ et al. (2008) demonstrated that TCA/ acetone method is reliable method for protein extraction for leaf tissues, while for root tissues, both TCA/acetone and phenol methods can be used. Protein extraction with
TCA/acetone base is one of the frequent protocols used to extract proteins from various samples, including plants and insects (Cilia et al. 2009; Wang et al. 2010; Xie et al. 2011; Xu et al. 2008; Yin et al. 2017; Zhang et al. 2015, 2013). TCA/acetone method is an effective method to minimize degradation of protein and to eliminate interfering substances, such as salt and polyphenols (Carpentier et al 2005; Gómez-Vidal et al. 2008; Görg et al. 2004). Besides, TCA/acetone method also suitable for extracting total protein including insoluble ones (Singh et al. 2015). In plant protein extraction, cold TCA/acetone $\left(-20^{\circ} \mathrm{C}\right)$ has been used for inactivation of proteases and removing several major interfering compounds, which can cause horizontal and vertical streaking, smearing on gel and reduction in the number of distinctly resolved protein spots (Saravanan \& Rose 2004; Wu et al. 2011).

TCA/acetone with DTT extraction method (Method C) was much simpler, economical and efficient for extracted protein from larva and adult $P$. xylostella compared to other TCA/acetone methods (Method A and B) with regard to both protein yield and intensity of protein spots. The differences between these methods are small but significant, which are the method of precipitation, type of reducing agents and the time of resuspending the pellet in lysis buffer. DTT is known to break the peptide bond of proteins and hence could improve protein solubility (Görg et al. 2004; Shaw \& Riederer 2003). 


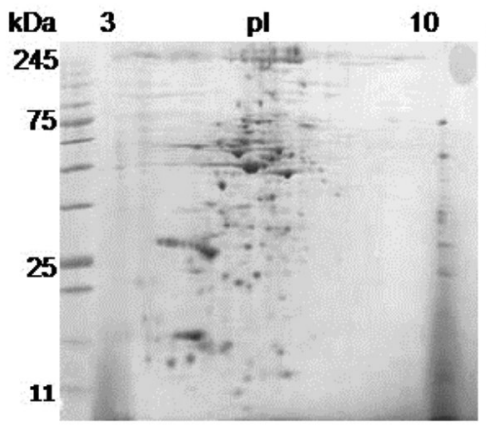

(a)

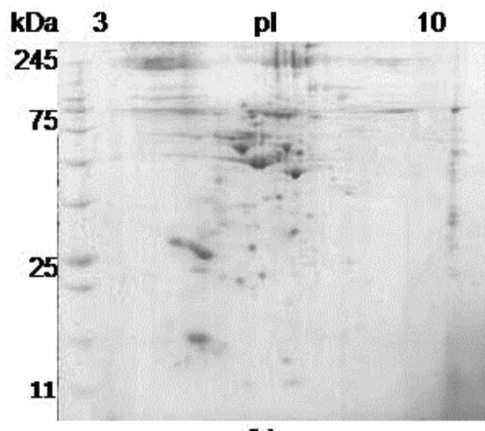

(b)

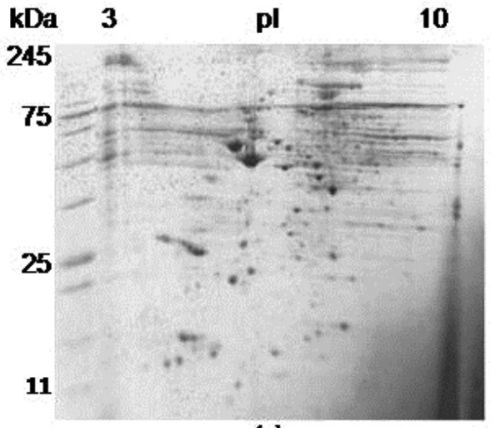

(c)

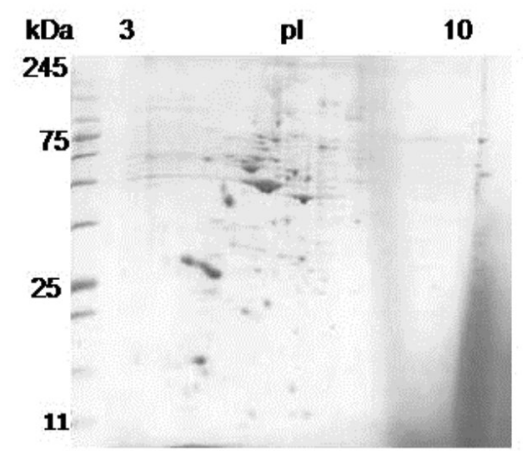

(d)

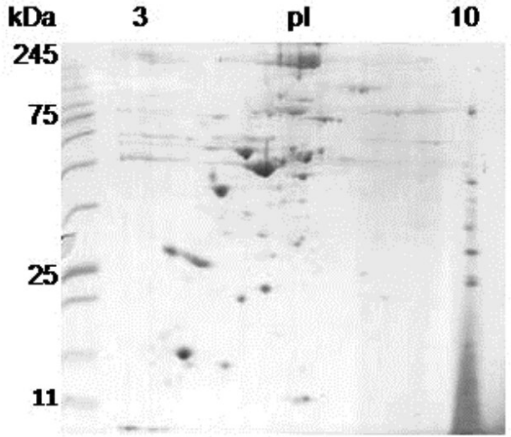

(e)

FIGURE 3. A comparison of P. xylostella adult protein extracted by different methods using 2-DE. The $7 \mathrm{~cm}, 12.5 \%$ SDS-PAGE gels were stain with CBB. (a) Method A, (b) Method B, (c) Method C, (d) Method D, (e) Method E

Protein concentrations and total protein contents for both Method D and E were either low and also protein profiles were not promising comparing to other methods. This might be due to tris-lysis buffer (Method D) contains a reactive primary amine that will react with aldehyde and ketones to form Schiff base adducts and then inhibit protein conjugation by amine-based cross linkers. Meanwhile, phosphate buffer (Method E) has an ability to inhibit the activity of several enzymes such as carboxypeptidase, urease, kinase and dehydrogenase (Ahmed 2005). Moreover, these methods (Method D and E) require more additional steps which might have caused proteins losses. Reducing the number of treatment steps in extraction method can help in preventing protein losses and at the same time, provide high-quality images, without additional step of cleanup to reduce background smear or to remove horizontal and/or vertical streaks (Rodrigues et al. 2012). The addition of protease inhibitor cocktail in both method $\mathrm{D}$ and $\mathrm{E}$ may modifiy proteins and cause charge artifacts (Görg et al. 2004).

\section{CONCLUSION}

Proteomics provides an effective way to show the biochemical mechanisms of insecticides resistance in insects. Proteins that differentially expressed during insecticide treatment can be quantitated through 2-DE and this study highlights the crucial importance of the protein extraction procedure in 2-DE. In this study, five protein extraction methods, including TCA/acetone buffer methods, tris- $\mathrm{HCl}$ buffer method and phosphate buffer method were evaluated with regard to protein concentration and yields and also intensity of protein spots. The TCA/acetone buffer with DTT showed a higher efficiency for protein extraction and separated the greatest number of protein spots on the gels for both larva and adult tissues. This extraction method therefore can be used in further works in order to analyze the proteome of P.xylostella and expected to be applicable for other Lepidopteran insects.

\section{ACKNOWLEDGEMENTS}

This study was supported by Fundamental Research Grant Scheme (FRGS/2/2014/ST04/UKM/02/2) funded by Ministry of Higher Education (MOHE) of Malaysia Government.

\section{REFERENCES}

Ahmed, H. 2005. Principles and Reactions of Protein Extraction, Purification, and Characterization. New York: CRC Press.

Alam, I., Sharmin, S.A., Kim, K.H., Kim, Y.G., Lee, J J. \& Lee, B.H.2012. An improved plant leaf protein extraction method for high resolution two-dimensional polyacrylamide gel electrophoresis and comparative proteomics. Biotechnic and Histochemistry 88: 61-75. 
Amadi,E.N. \& Kiin-Kabari, D.B. 2016. Nutritional composition and microbiology of some edible insects commonly eaten in Africa, hurdles and future prospects: A critical review. Journal of Food Microbiology Safety and Hygiene 1: 1-7.

Bates, S.L., Zhao, J.Z., Roush, R.T. \& Shelton, A.M. 2005. Insect resistance management in GM crops: Past, present and future. Nature Biotechnology 23: 57-62.

Bradford, M.M. 1976. A rapid and sensitive method for the quantitation of microgram quantities of protein utilizing the principle of protein-dye binding. Analytical Biochemistry 72: $248-254$.

Carpentier, S.C., Witters, E., Laukens, K., Deckers, P., Swennen, R. \& Panis, B. 2005. Preparation of protein extracts from recalcitrant plant tissues: An evaluation of different methods for two-dimensional gel electrophoresis analysis. Proteomics 5: 2497-2507.

Chatterjee, M., Gupta, S., Bhar, A. \& Das, S. 2012. Optimization of an efficient protein extraction protocol compatible with two-dimensional electrophoresis and mass spectrometry from recalcitrant phenolic rich roots of chickpea (Cicer arietinum L.). International Journal of Proteomics 2012: 536963.

Cilia, M., Fish, T., Yang, X., Mclaughlin, M., Thannhauser, T.W. \& Gray, S. 2009. A comparison of protein extraction methods suitable for gel-based proteomic studies of aphid proteins. Journal of Biomolecular Technique 20: 201-215.

Colinet, H., Renault, D., Charoy-Gue'vel, B. \& Com, E. 2012. Metabolic and proteomic profiling of diapause in the aphid parasitoid Praonvolucre. PLoS ONE 7: e32606. doi: 10.1371/ journal.pone.0032606.

Collet, J. \& Baguñà, J. 1993. Optimizing a method of protein extraction for two-dimensional electrophoretic separation of proteins from planarians (Platyhelminthes, Turbellaria). Electrophoresis 14: 1054-1059.

Dong, X., Zhai, Y., Hu, M., Zhong, G., Huang, W., Zheng, Z. \& Han, P. 2013. Proteomic and properties analysis of botanical insecticide rhodojaponin III-induced response of the diamond back moth, Plutella xyllostella (L.). PloS ONE 8: e67723.

Etebari, K., Bizhannia, A.R., Sorati, R. \& Matindoost, L. 2007. Biochemical changes inhaemolymph of silkworm larvae due to pyriproxyfen residue. Pesticide Biochemistry and Physiology 88: 14-19.

Gómez-Vidal, S., Tena, M., Lopez-Llorca, L.V. \& Salinas, J. 2008. Protein extraction from Phoenix dactylifera L. leaves, a recalcitrant material, for two-dimensional electrophoresis. Electrophoresis 29: 448-456.

Görg,A., Weiss, W. \& Dunn, M.J. 2004. Current two-dimensional electrophoresis technology for proteomics. Proteomics 4: 3665-3685.

Isaacson, T., Damasceno, C.M., Saravanan, R.S., He, Y., Catalá, C., Saladié, M. \& Rose, J.K. 2006. Sample extraction techniques for enhanced proteomic analysis of plant tissues. Nature Protocols 1: 769-774.

Khani, A., Moharramipour, S., Barzegar, M. \& Naderi-Manesh, H. 2007. Comparison of fatty acid composition in total lipid of diapause and non-diapause larvae of Cydiapomonella (Lepidoptera: Tortricidae). Insect Science 14: 125-131.

Konus, M., Koy, C., Mikkat, S., Kreutzer, M., Zimmermann, R., Iscan, M. \& Glocker, M.O. 2013. Molecular adaptations of Helicorvepaarmigera midgut tissue under pyrethroid insecticides stress characterized by differential proteome analysis and enzyme activity assays. Comparative Biochemistry and Physiology 8: 152-162.
Laemmli, U.K. 1970. Cleavage of structural proteins during the assembly of the head of bacteriophage T4. Nature 227: 680-685.

Li, J., Li, F.L., Jiae, D.X., Li, N. \& Cheng, L.G. 2014a. Proteomic analysis of differentially expressed proteins in larvae of the diamondback moth, Plutella xylostella (Lepidoptera: Plutellidae), under deltamethrin stress. Acta Entomologica Sinica 57: 36-44.

Li, Q., Wang, D., Lv, S. \& Zhang, Y. 2014b. Comparative proteomics and expression analysis of five genes in Epicauta chinensis larva from the first to fifth instar. PLOS ONE 9: e89607.

Mahmoudvand, M.,Abbasipour,H., Garjan,A.S. \& Bandani,A.R. 2011. Sublethal effects of hexaflumuron on development and reproduction on the diamondback moth, Plutella xylostella (Lepidoptera: Yponomeutidae). Insect Science 18: 689-696.

Qin, L., Shi, H., Xia, H., Wang, Y., Chen, L., Yao, Q. \& Chen, K. 2013. A robust protein extraction method for two dimensional electrophoresis of silkworm proteins. Advances in Bioscience and Biotechnology 4: 584-589.

Rasool, K.G., Khan, M.A., Aldawood,A.S., Tufail, M., Mukhtar, M. \& Takeda, M. 2014. Optimization of protein isolation from date palm plants and its utilization in differential proteomics associated with red palm weevil infestation. Pakistan Journal of Agricultural Sciences 51: 907-917.

Rodrigues, E.P., Torres, A.R., Batista, J.S., Huergo, L. \& Hungria, M. 2012. A simple, economical and reproducible protein extraction protocol for proteomics studies of soybean roots. Genetics and Molecular Biology 35: 348-352.

Saravanan, R.S. \& Rose, J.K.C. 2004. A critical evaluation of sample extraction techniques for enhanced proteomic analysis of recalcitrant plant tissues. Proteomics 4: 2522-2532.

Seman-Kamarulzaman, A.F., Mohamed-Hussein, Z.A., Ng, C.L. \& Hassan, M. 2016. Novel NAD ${ }^{+}$-farnesal dehydrogenase from Polygonum minus leaves. Purification and characterization of enzyme in juvenile hormone III biosynthetic pathway in plant. PLOS ONE 11:e161707.

Shashank, P.R. \& Bollineni, H. 2014. Insect proteomics: Present and future prospective. Current Biotica 7: 336-342.

Shaw, M.M. \& Riederer, B.M. 2003. Sample preparation for twodimensional gel electrophoresis. Proteomics 3: 1408-1417.

Singh, N., Jain, N., Kumar, R., Jain, A., Singh, N.K. \& Rai, V. 2015. A comparative method for protein extraction and 2-D gel electrophoresis from different tissues of Cajanus cajan. Frontiers in Plant Science 6: 606-612.

Vincent, D., Wheatley, M.D. \& Cramer, G.R. 2006. Optimization of protein extraction and solubilization for mature grape berry clusters. Electrophoresis 27: 1853-1865.

Wang, X., Chang, L., Wang, G., Sun, Z., Ma, H., Sun, Q. \& Li, J. 2010. Protein extraction from the earthworm Eisenia fetida for 2-DE. Proteomics 10: 1095-1099.

Wang, Y., Lin, D.S., Bolewicz, L. \& Connor, W.E. 2006. The predominance of polyunsaturated fatty acids in the butterfly Morpho peleides before and after metamorphosis. Journal of Lipid Research 47: 530-536.

Wu, Q., Li, C., Ke, L., Jiao, C., Jiang, J., Sun, X., Li, F. \& Wang, C. 2011. A high-efficiency, two-dimensional gel electrophoresis platform for mature leaves of grass pea (Lathyrus sativus L.). Acta Physiologiae Plantarum 33: 2387-2397.

Xie, C., You, M.S., Cheng, J. \& Vasseur,L.A. 2011. A proteomic analysis of short-term exposure to fipronil in larva of Plutella xylostella. African Journal of Biotechnology 10: 1759917609. 
Xu, C., Zhang, Z., Cui, K., Zhao, Y., Han, J., Liu, F. \& Mu, W. 2016. Effects of sublethal concentrations of cyantraniliprole on the development, fecundity and nutritional physiology of the black cutworm Agrotis ipsilon (Lepidoptera: Noctuidae). PLOS ONE 11(6): e0156555.

Xu, C., Xu, Y. \& Huang, B. 2008. Protein extraction for twodimensional gel electrophoresis for proteomics profiling in turfgrass. Crop Science 48: 1608-1614.

Yin, F., Lin, Q.S., Feng, X., Chen, H.Y., Li, Z.Y. \& Hu, Z.D. 2017. Analysis of differentially expressed proteins between the spinetoram-susceptible and -resistant strains of Plutella xylostella (L.). Journal of Asia Pacific Entomology 20: 119-124.

Yiou, P., Shaoli, A., Kebin, L., Tao, W., Kui, F., Hua, Z., Yu, S., Xun, Y. \& Jinghui, X. 2013. Evaluation of extraction procedures for 2-DE analysis of aphid proteins. Journal of Separation Science 36: 532-539.

Zalucki, M.P., Shabbir, A., Silva, R., Adamson, D., Shu-Sheng, L. \& Furlong, M.J. 2012. Estimating the economic cost of one of the world's major insect pests, Plutella xylostella (Lepidoptera: Plutellidae): Just how long is a piece of string? Journal of Economic Entomology 105: 1115-1129.

Zhang, N.N., Zhang, H., Cheng, C., Li, F.L., Gao, S.Q. \& Cheng, L.G. 2013.A comparative profiling of protein expression in the deltamethrin-sensitive and resistant strains of the diamondback moth (Plutella xylostella). Acta Entomologica Sinica 56: 1-8

Zhang, S., Zhang, L.L., Zhu, K.K., Liu, Y.J. \& Zhao, Z. 2015. Evaluation of three types of protein extraction methods for tetraploid black locust (Robinia pseudoacacia L.) phloem tissue proteome analysis by two-dimensional electrophoresis. Analytical Methods 7: 1008-1017.
Zheng, Q., Song, J., Doncaster, K., Rowland, E. \& Byers, D.M. 2007. Qualitative and quantitative evaluation of protein extraction protocols for apple and strawberry fruit suitable for two-dimensional electrophoresis and mass spectrometry analysis. Journal of Agricultural and Food Chemistry 55: 1663-1673.

Maizom Hassan*, NorazilaYusoff \& Wan Mohd Aizat Institute of Systems Biology (INBIOSIS)

Universiti Kebangsaan Malaysia

43600 UKM Bangi, Selangor Darul Ehsan Malaysia

Nurul Wahida Othman \& Idris Abd Ghani

School of Environmental and Natural Resources Sciences

Faculty of Science and Technology

Universiti Kebangsaan Malaysia

43600 UKM Bangi, Selangor Darul Ehsan

Malaysia.

*Corresponding author; email: maizom@ukm.edu.my

Received: 30 May 2018

Accepted: 19 September 2018 